\title{
LAST CLEAR CHANCE: A TRANSITIONAL DOCTRINE
}

\author{
By FLEMING JAMES, Jr. $\dagger$
}

THE RULE that a plaintiff, though negligent himself, may nevertheless recover from a defendant who had the last clear chance to avoid injuring him, is no more to be accounted for by the legal reasoning generally used to sustain it than is any other rule of law. The iconoclast of yesterday rent the veil of rationalization and exposed economic and political factors and philosophies as the inarticulate major premises underlying legal decision. We may readily concede his thesis. Yet the fact that these premises are inarticulate of itself has some effect in directing the course of a trend, and leaves no little room for rationalization and explanation to give it shape-sometimes to distort it. Here we shall try to study the legal principles and formulae which have been thought to explain the rule in question, and to trace the influence these have had in giving it the various forms it has taken in different jurisdictions. We can then, perhaps, evaluate these influences in the light of the broad purposes which the rule may be useful in serving, and, on the basis of this appraisal, indicate the future changes which the doctrine is likely to undergo.

\section{I.}

The rule that a plaintiff in an action based on negligence is barred from recovery by his own negligence first found clear expression at about the beginning of the nineteenth century. Its announcement does not seem to have been regarded as a startling thing, and it probably represented no innovation. ${ }^{1}$ But its limits and its heritage were by no means clearly defined. The first decisions (1798-1810) setting forth the rule dealt with cases where the plaintiff's negligence was later in point of time than defendant's. ${ }^{2}$ They could be accounted for quite readily in terms of what Holdsworth calls "the medieval principle that the plaintiff, having in effect been damaged by [his] own act, and not by the act of the defendant, could not recover." 3 Not the negligent quality of plaintiff's act but the directness of its relation to his injury

†Associate Professor, Yale School of Law.

1. Beach, Contributory Negligence (3d ed. 1899) §8; Bohlen, Contributory Negligence (1908) 21 Harv. L. Rev. 233; 8 Holdsworth, History of English Law (1922) 459.

2. Cruden v. Fentham, 2 Esp. 685 (K. B. 1798); Clay v. Wood, 5 Esp. 44 (K. B. 1803) ; Butterfield v. Forrester, 11 East 60 (K. B. 1809); Flower v. Adam, 2 Taunt. 314 (C. P. 1810).

3. 8 Holdsworth, History of English Law (1922) 460. 
was the gist of the defense, if that was the governing principle. In this view, the question as to whose wrongful act came last in point of time would be crucial; and some of the language of these decisions indicates that it was so regarded."

At this time, however, medieval notions were giving ground. The idea of negligence as a basis of liability had taken strong root and had already been recognized. The factors which brought about this change would naturally tend to cause a shift in emphasis in evaluating the plaintiff's conduct as well. The same individualistic climate of opinion which privileged a defendant's activity to harm others, so long as it was not negligently carried on, would be likely to require those others to use care for their own safety before they were afforded redress for their injuries in the courts. ${ }^{5}$ In this view, the question of whether conduct was blamable would eclipse the inquiry into whose act was last. Something like this rather than any "medieval principle" seems to underlie later (i.e., after 1810) decisions in the courts of Kings Bench and Common Pleas, for in these tribunals no attention was paid to the timing of the parties' respective negligences until after the decision of Davies v. $\operatorname{Mann}^{6}$ in 1842 .

Vanderplank v. Miller ${ }^{7}$ was apparently a last clear chance case. Plaintiffs' boat, while anchored, was run down by defendant's boat. There was evidence that the latter "if carefully and skilfully navigated, might have avoided ... " the collision. There was also evidence that plaintiffs' crew were all below, and if any of them had been on deck "they might, by a slight shifting of the position of the Louisa as she lay at anchor, have avoided the shock of the Robert and $A m n$, and the accident would not have happened." In the charge, the jury was told "If there was want of care on both sides, the plaintiffs cannot maintain their action." The plaintiffs had a verdict.

In Luxford v. Large, ${ }^{8}$ also, the fact that defendant may have had the latest opportunity to avoid the loss seems to have been disregarded. Plaintiff claimed his boat was swamped by the swell from defendant's steamer. There was evidence that the former was overloaded. In summing up, Chief Justice Denman told the jury the two points at issue

4. E.g., in Flower v. Adam, 2 Taunt. 314 (C. P. 1810), Mransfield, C. J, thought the defendant's wrong "too remote to affect" him, and Lawrence, J., stated, "The immediate and proximate cause is the unskilfulness of the driver."

5. Bohlen, loc. cit. sipra note 1; 8 Holnsworth, History of Errgusa Law (1922) $446-462$.

6. $10 \mathrm{M} . \&$ W. 546 (Ex 1842).

7. M. \& M. 169 (K. B. 1828); cf. Lack v. Seward, 4 C. \& P. 105 (K. B. 1829), a somewhat similar case in which the jury was told that defendant would not be liable "if the accident could have been avoided, but for the negligence of the plaintiff's men in not being on board his barge at a time when it was lying in a dangerous place."

8. 5 C. \& P. 421 (K. B. 1833). 
were whether defendant's steamer caused the swell and whether plaintiff's boat was overloaded, and said, "If you think . . . that it was the plaintiff's own negligence in loading his boat as he did, which occasioned the injury, then you cannot find any verdict against the defendant. -. . If you are satisfied that the defendant's vessel occasioned the injury by its improper speed, and that the plaintiff was not in fault, and did not contribute to his misfortune by his improper management of his boat, then you will find for the plaintiff." They did.

In Pluckwell $v$. Wilson, ${ }^{9}$ a highway collision case, the negligences, if any, were probably contemporaneous. Mr. Justice Alderson left it to the jury to say whether the injury was caused by defendant's negligence "without any negligence on the part of the plaintiff himself; for that if plaintiff's negligence in any way concurred in producing the injury, the defendant would be entitled to a verdict." Sills v. Brown ${ }^{10}$ appears to have involved later negligence on plaintiff's part, but that fact was not noticed by the court or counsel, and the charge made the issue turn on whether plaintiff's fault "substantially contributed to the occurrence of the injury."

Further evidence of this attitude which stressed fault rather than directness is afforded by Raisin $v$. Mitchell. ${ }^{11}$ On conflicting evidence the court charged that plaintiff could not recover if the injury was "imputable in any degree" to his want of care. The jury returned a verdict for one half the plaintiff's damage, explaining "that there were faults on both sides." Defendant claimed this entitled him to a verdict, but Chief Justice Tindal answered "No. There may be faults to a certain extent," and let the verdict stand. Now this could fit in well enough with a scheme of liability based on negligence, ${ }^{12}$ but, as Holdsworth points out, it is quite incompatible with the "medieval principle." 13

The older notion was far from dead, however, and found a champion in the Court of Exchequer. In Bridge v. Grand Junction Ry. Co., ${ }^{14}$ a plea that plaintiff's injury was caused in part by default of those under whose guidance he was, "as well as in part by the default . . . " of defendant, was held bad in substance for failing to show that the negligence chargeable to plaintiff lay "in not avoiding the consequences of the defendant's default." ${ }^{15}$ Thus, plaintiff's negligence, unless it was

9. 5 C. \& P. 375 (C. P. 1832). To like effect is Williams v. Holland, 6 C. \& P. 23 (K. B. 1833).

10. 9 C. \& P. 601 (Q. B. 1840).

11. 9 C. \& P. 613 (C. P. 1839).

12. Lowndes, Contributory Negligence (1934) 22 GEo. L. J. 674, 683; see The Bernina, 12 P. D. 58,89 (C. A. 1887).

13. 8 HoldswoRTH, op. cit. supra note 1 , at 459,462 n. 3.

14. 3 M. \& W. 244 (Ex. 1838).

15. Id., at 247. The particular quotation is from Parke, B., arguendo, but it is repeated in substance by Lord Abinger, arguendo, and in Baron Parke's opinion. 
later than defendant's and so the direct cause of the injury, was not available as a defense. Davies $v$. Man:n ${ }^{16}$ went no further than this. The rule is a limitation which inheres in the defense of contributory negligence itself (rather than one which avoids the effect of contributory negligence), and the limitation is a logical application of the medieval principle. It is amusing to see how this faithfulness to an older orthodoxy was branded as novel and heretical by later writers who had come naively to assume that the defense of contributory negligence, in its unspoiled original simplicity, extended to any fault on plaintiff's part, and necessarily was a total bar to his action. ${ }^{17}$ Neither source of the rule would have warranted both branches of this assumption; yet both might have stood together, for all that, if the net result had been in line with prevailing notions of social policy, fairness, and ethics.

As later events have proven, however, the wind did not set in that quarter. We can now say it was inevitable that the rule of contributory negligence would not be pushed to this rather illogical extreme. Just why the chief limitation upon it came to be rationalized along the archaic lines charted out by Davies $v$. Manu rather than the more modern ones indicated in Raisin v. Mitchell ${ }^{18}$ need not detain us here. ${ }^{10}$ The fact is it did, both in England ${ }^{20}$ and in this country. The task we have set ourselves is to discover the results, not the causes, of this fact.

According to the typical modern judicial statement, the last clear chance rule is no more than a logically necessary deduction from the principles of proximate cause. ${ }^{21}$ Under it plaintiff can recover because his negligence is but a "condition" or "remote cause" of his injury, the defendant's wrong its sole "proximate cause." Now it must be obvious at once that this explanation cannot stand the most superficial analysis if it purports to apply to plaintiff the tests of legal cause generally used today in the inquiry as to a defendant's liability. This has often been demonstrated. ${ }^{22}$ Certainly if a man's negligence has put himself or his

16. 10 M. \& W. 546 (Ex. 1842).

17. Beach, Contributory Negligence (3d ed. 1899) §\$10-13; Th02rsso:; NeghGENCE (1901) $\$ \S 230,233$.

18. 9 C. \& P. 613 (C. P. 1839).

19. See Mole \& Wilson, A Study of Comparative Negligence (1932) 17 Coss I. Q. 333, 604 .

20. Mayor of Colchester v. Brooke, 7 Q. B. 339 (1845); Dimes v. Petley, 15 Q. B. 276 (1850); Dowell v. General Steam Nav. Co. 5 E. \& B. 195 (Q. B. 1855); Tuff v. Warman, 5 C. B. N. S. 573 (Ex. Ch. 1858); Springett v. Ball, 4 F. \& F. 472 (Q. B. 1865); Radley v. London \& N. W. Ry. Co., 6 A. C. 754 (H. L. 1876).

21. See cases collected in Green, Contributory Negligence and Proxinate Canse (1927) 6 N. C. I. Rev. 3, 23-25, and n. 50; Note (1934) 92 A. L. R. 47, 48-54, and n. 8; 1 Street, Foundation of Legar Linbinity (1906) 127, 134; 1 Tho:mpson; Negirgence (1901) $\$ \$ 240,241$. An opinion reasoned out elaborately along this line is to be found in Nehring v. Connecticut Co., 86 Conn. 109, 84 Atl. 301 (1912).

22. Salzrond, ToRTS (8th ed. 1934) 483-487; Bohlen, Contribulory Neglighere (1908) 21 HARv. L. Rev. 233, 257-8; Green, op. cit. supra note 21, at 21-30; Lowndes, 
property in a position of peril, that negligence is a proximate cause of the injury which follows when the perils of the position become realized. In such case the likelihood of the danger that befell was one of the very things that made his original act negligent, and probable consequences are proximate ones. ${ }^{23}$ This is no less true when the danger comes from the foreseeable tortious intervention of a responsible being. Here too a third person injured by the event may hold the earlier as well as the later wrongdoer. ${ }^{24}$ Yet this last proposition has not always commanded unquestioning recognition. "There was prevalent in the early part of the nineteenth century, just at the time when the earliest cases of contributory negligence were decided, a principle of limitation of liability, purely legal, the creature of judicial rather than popular conception of justice, stopping recovery short of either the probable or natural result of the act complained of." ${ }^{25}$ This rule would permit an injured plaintiff to hold only the last responsible actor whose wrong contributed to his injury. Its kinship to the "medieval principle" of Holdsworth is manifest. As a limitation on defendant's liability the principle is almost obsolete, but it has kept its vitality as a limitation on the defense of plaintiff's contributory negligence. It is in the light of this last-wrongdoer rule that the "causal" relationship between plaintiff's wrong and his injury is to be tested under the current rationalization of last clear chance. Put in a more forthright but less historically revealing way: "When an accident happens through the combined negligence of two persons, he alone is liable to the other who had the last opportunity of avoiding the accident by reasonable care." ${ }^{26}$

Two further aspects of the legal reasoning now in vogue in these cases deserve mention: (1) Some courts repudiate the last opportunity rule as such and confine recovery by a contributorily negligent plaintiff to cases where the defendant's conduct is found to be wilful or wanton. ${ }^{27}$ (2) Nearly all courts which espouse the rule have, since the beginning,

Contributory Negligence (1934) 22 GEo. L. J. 674, 702-705; cf. Pollock, The LAw of ToRTs (12th ed. 1923) 469. Nothing could make this dual sense of "proximate cause" clearer than a case like Colorado \& S. Ry. Co. v. Western L. \& P. Co., 73 Colo. 107, 214 Pac. 30 (1923), where one wrongdoer, having been compelled by judgment to pay damages to an innocent third person, is allowed to recover those damages from another wrongdoer who had, as between the two, a last clear chance.

23. Smith, Legal Catise in Actions of Tort (1911) 25 HARv. L. REv. 103, 114 et seq.; Carpenter, Workable Rules for Determining Proximate Cause (1932) 20 Catrf. L. REv. 229, 238.

24. Illidge v. Goodwin, 5 C. \& P. 190 (C. P. 1831); Lynch v. Nurdin, 1 A. \& E. 29 (Q. B. 1841) ; Harper, LaW OF TORTS (1933) $\$ 123$.

25. Bohlen, Contributory Negligence (1908) 21 HARv. L. Rev. 233, 236.

26. SALMOND, LAw of TORTS (8th ed. 1934) 480.

27. See Spillers v. Griffin, 109 S. C. $78,81,95$ S. E. 133, 134 (1917). But see 1 Shearman \& Redfield, Negligence (6th ed. 1913) $\$ 99$, stating that no court of last resort any longer disputes this rule. 
steadfastly repudiated the notion that it is based in any measure upon a comparison of faults. ${ }^{28}$

Next we shall try to see how the actual decisions fit these doctrinal formulae, how their course has been shaped by them, if at all. In doing this it will be well to begin with those situations which are covered by orthodox explanations.

\section{II.}

There is one class of cases which represents the last clear chance in its simplest, least controversial form. Where the plaintiff or his property is in actually helpless peril and is seen there by the defendant, the latter will everywhere be held liable if he could reasonably have prevented the accident after he saw the danger and after he realized, or in the exercise of due care should have realized, the plaintiff's helplessness. ${ }^{20}$ There is no dearth of theories to explain this result. Some call the defendant wanton, ${ }^{30}$ and this will do well enough except where his failure was too patently a mere error in judgment, or an awkward or sluggish reaction. Others prefer to say simply that the defendant has the last clear chance ${ }^{31}$ (as though these words were a statement of the doctrine they refer to), and so he has as most people would regard it. It might be asked why we take account of the plaintiff's helplessness and disregard the defendant's inability to alter his own physiological and psychological shortcomings. Perhaps it is a sufficient answer that the distinction is commonly made. We recognize the state of the man dead drunk as helpless, while we are far more likely to view the opportunities of the confused, inept, or slothful man as clear enough if he only would take them. After all, the law has never accepted extensively the tenets of philosophic determinism.

Generally, however, courts explain holding the defendant in these cases in terms of proximate cause. ${ }^{32}$ The explanation can be phrased

28. Id., at § 102; Thompson, NeGLigeNcE (1901) §259.

29. Note (1934) 92 A. L. R. 47, 83-86 and cases in n. 41. Examples are Nicolai v. Pac. El. Ry., 92 Cal. App. 100, 267 Pac 758 (1928) ; Bragg v. Central N. E. Ry., 228 N. Y. 54, 126 N. E. 253 (1920). Of course it is possible for plaintiff to prove circumstantially that defendant saw him, even over the latter's denial. Amold $v$. Owens, 78 F. (2d) 495 (C.C.A. 4th, 1935); Groves v. Webster City, Iowa, 222 Iowa 849,270 N. W. 329 (1936).

30. Esrey v. Southern Pac. Co., 103 Cal. 541, 37 Pac 500 (1894); Tempfer v. Joplin \& P. Ry., 89 Kan. 374, 131 Pac. 592 (1913).

31. See Rasmussen v. Fresno Tr. Co., 15 Cal. App. (2d) 356, 362, 59 P. (2d) 617, 619 (1936) ; Keller v. Norfolk \& W. Ry., 109 W. Va. 522, 528, 156 S. E. 50, 52 (1930).

32. Bragg v. Central N. E. Ry., 228 N. Y. 54, 126 N. E. 253 (1920); sce Nehring v. Connecticut Co., 86 Conn. 109, 120, 84 Atl. 301, 305 (1912); Rottman v. Beverly, 183 La. 947, 955, 165 So. 153,155 (1936). 
logically, too, if only we remember that in this connection proximate cause is to be read in the light of the "last wrongdoer" limitation. The wrong of the plaintiff is past and has culminated - it has come to rest, albeit in danger. After he could no longer help himself, plaintiff has been guilty of no fresh wrongful act or omission, though to be sure the courts, if they were concerned with his liability to a third person injured by the mishap, would be quick enough to say that the consequences of the old one continued as long as the danger lasted..$^{33}$ The defendant's negligence, in the cast put, occurs later in point of time than plaintiff's does, and there is nothing artificial or forced in calling him the last wrongdoer.

This last-wrongdoer reasoning is an adequate logical rationalization of two other types of cases also:

1. When the defendant does not see but in the exercise of due care should have seen and appreciated the plaintiff's helpless peril in time to avoid injuring him, he will be held liable in most jurisdictions. ${ }^{84}$ Frequently, here, the defendant can hardly be called wanton. It is harder, too, to say he had a last clear chance, since his unawareness may be thought to make the word "clear" inappropriate. ${ }^{35}$ For one or the other of these reasons some courts deny a recovery in this situation, limiting the doctrine to one of "discovered peril." 36 But here also defendant's

33. It is sometimes said that the negligence of such a one continues during every moment he is in peril. But for the purpose of selecting a last wrongdoer it is perfectly clear that remaining in peril is a continuing fresh wrong at most, only so long as escape is actually possible on the state of things as they are at the time (save only for plaintiff's inadvertence or ineptitude). Were this not so defendant's wrong would never be the later.

34. A good collection of these cases is to be found in Note (1934) 92 A. L. R. 47, 101 et seq. This contains a useful review of the authorities. See also Harper, LAW of Torts (1933) §138; Thompson, Negligence (1901) §239. Of course it cannot be said that defendant "should have seen" plaintiff unless there was a duty to be on the lookout for him. So a trespasser injured at a place where his presence was not to be expected would have to show that he had actually been seen even under these cases. 1 THOMPSON, Negligence (1901) §§ 232, 236.

35. Ordinarily it matters little whether the rule be phrased in terms of last opportunity or of last wrongdoing. Failure to take the one amounts to the other. But those who insist that the later chance be a "clear" one (as that word is used in the cases referred to) add a qualitative requirement to the test which is not warranted by the "medieval principle." The early authorities were satisfied by a defendant's intervening fault even where that included a negligent failure to see the danger. Davies v. Mann, 10 M. \& W. 546 (Ex. 1842) ; Springett v. Ball, 4 F. \& F. 472 (Q. B. 1865). Of course there is no reason why "clear" should not be more broadly defined, and it usually is. See, e.g., Leinback v. Pickwick Greyhound Lines, 138 Kan. 50, 65, 23 P. (2d) 449,456 (1933) ("a chance is a clear chance if exercise of vigilance would have discovered the helpless peril and avoided the injury.")

36. Woloszynowski v. New York Cent. R.R., 254 N. Y. 206, 172 N. E. 471 (1930); Srogi v. New York Cent. R.R., 247 App. Div. 95, 286 N. Y. Supp. 215 (4th Dept. 1936) ; Cleveland R.R. v. Masterson, 126 Ohio 42, 183 N. E. 873 (1932). 
wrong is later than plaintiff's; after it had become impossible for the latter to get out of trouble, the former still could have controlled the situation, if only he had taken the precautions he was legally bound and physically able (except for his preoccupation, or the like) to take. This is another instance where, in Professor Bohlen's apt words, plaintiff's fault is want of "pre-caution," defendant's a want of "caution in the crisis."

2. There is another kind of case in which the plaintiff's peril is not actually helpless, but where the only effective precaution he could take is one that could not be expected of ordinary men. ${ }^{38} \mathrm{~A}$ combination of his own and the defendant's carelessness, for instance, may have put him in a sudden dilemma. If he then acts as prudently as people generally do, in view of the emergency, and is injured because he chose what in the event proved to be the wrong course, the defendant may still be the last wrongdoer. $\mathrm{He}$ is whenever he has a reasonable chance to avoid the accident after the plaintiff is in the predicament described. The plaintiff's last act, though it was a failure to take a way of escape actually open, was not a wrongful act. At first glance this may seem to conflict with the notion that a man cannot excuse himself simply because he has acted with ordinary care in an emergency which his own prior carelessness has helped to create. There is no such conflict. In this, as in all the other situations we treat, the consequences of the plaintiff's negligence continue up to the final injury. If tardy carefulness does not break the chain of cause, neither does helpless peril. We are not looking for a break in the chain of cause in that sense. We are satisfied to find the act of a wrongdoer intervening between the last negligent act or omission of the plaintiff and his injury.

The last wrongdoer principle can be stretched to fit one other situation. That is the case where an inadvertent plaintiff, who is already in peril but could step out of it until the very last moment if he but used his senses as he should, is injured by a defendant who sees or should see him in time for a reasonable man to appreciate and avoid the danger. It is true that the last opportunity and last breach of duty may be with the plaintiff. But his fault is a mere omission, a failure to escape; the defendant's fault actively increases the peril after plaintiff's has ceased to do so. Logically, there is no particularly good reason why both should not count as wrongs in the search for a last wrongdoer. Yet there is some basis in tradition for distinguishing between active and passive misconduct, and perhaps some doctrinal respectability could be claimed

37. Bohlen, Contributory Negligence (1908) 21 Hanv. L. REv. 233, 257, Studres IN: LAw of Tozrs 500, 530 et seq.

38. Such a situation was presented in Bence v. Teddy's Taxi, 112 Cal. App. 636, 297 Pac. 128 (1931); Schaaf v. Coen, 131 Ohio 279, 2 N. E. (2d) 605 (1936). 
for refusing to regard the passive kind as amounting to a fresh wrong. ${ }^{30}$ .Clearly, though, this reasoning would warrant no distinction at all between cases where the defendant sees and those where he should but does not see plaintiff. ${ }^{40}$ Nevertheless the distinction is widely made; and the defendant is generally said to have the last clear chance in the former but not in the latter situation. ${ }^{41}$

Next we come to those cases which simply do not fit the formula no matter how much we stretch it. Among them, too, we find the same unaccountable diversity of treatment. Let us first examine a pair of cases very much like those just considered. When a defendant sees a plaintiff approaching peril, the plaintiff who is negligently inadvertent or preoccupied will often be the last wrongdoer. Frequently he could avoid the accident up until the very last moment by taking the simplest of precautions - precautions readily available to him, which the most ordinary prudence demands. ${ }^{42}$ Appreciably before this time the defendant

39. See the analysis in Nehring v. Connecticut Co., 86 Conn. 109, 120, 84 At1. 301, 305 (1912).

40. And some courts apply it without regard to any such distinction. Tullock v. Connecticut Co., 94 Conn. 201, 108 Atl. 556 (1919); Wilfong v. Omaha \& C. B. St. Ry., 129 Neb. 600, 262 N.W. 537 (1935); Malfetano v. United El. Rys., 191 Atl. 491 (R. I. 1937).

41. In all the following cases plaintiff was unaware of his danger but otherwise would have had the last chance to escape: (a) defendant also unaware of plaintiff's peril: plaintiff treated as last wrongdoer and so barred of recovery in Dyerson $v$. Union Pac. R.R., 74 Kan. 528, 87 Pac. 680 (1906) ; Harrison v. Louisiana W. R.R., $132^{\circ}$ La. 761, 61 So. 782 (1913) ; Hickey v. Smith, 277 Mich. 123, 268 N. W. 833 (1936); Southern Ry. v. Bailey, 110 Va. 833, 67 S. E. 365 (1910); see also cases collected in BOHLEN, CASES ON TORTS (3d ed. 1930) 542, n. 25. (b) defendant aware of plaintiff's peril: plaintiff allowed to recover in spite of his last wrongdoing in Darling v. Pacific El. Ry.; 197 Cal. 702, 242 Pac. 703 (1925); Groves v. Webster City, Iowa, 222 Iowa 849, 270 N. W. 329 (1936) ; Monk v. Crowell \& Spence L. Co., 168 So. 360 (La. App. 1936) ; Dobson-Peacock v. Curtis, 166 Va. 550, 186 S. E. 13 (1936); see cases collected in Note (1934) 92 A. L. R. 47, 86 et seq. The American Law Institute draws the same distinction. Restatement, Torts (1934) $\$ \$ 479,480$.

A defendant will not be held where he has no reason to suppose the plaintiff will stay in danger until it is too late to save him; that would be true in any of these cases. A defendant who sees the plaintiff may assume he will be careful, and escape, until something unusual about the situation indicates the contrary. Panarese v. Union R.R., 261 N. Y. 233, 185 N. E. 84 (1933). A defendant who fails to see, through carelessness, may have the benefit of an analogous assumption. Virginia El. \& $P$. Co. v. Ford, 166 Va. 619, 186 S. E. 84 (1936). Some of the cases in this note which exonerate the defendant might be placed on this ground. Southern Ry, v, Bailey, supra, is an example. Compare it with Virginia Ry. \& P. Co. v. Smith \& Hicks, 129 Va. 269, 105 S. E. 532 (1921).

42. In a few situations the plaintiff becomes unable to avoid injury by the exercise of due care, before he comes into the actual path of danger from defendant's vehicle. In such case he is already in helpless peril at the earlier point. His lot is not like that of the plaintiff who still can stop before encountering danger, if he would but 
may have lost entire control over the situation. If he has, to call him the last wrongdoer is a mere tour de force and one which cannot be justified even by the tenuous borderline between active and passive misconduct. This is no whit less true where the defendant could by exercise of due care have prevented the accident before things got out of hand. After his negligent failure to do so comes plaintiff's negligent failure to see, to appreciate, and to avoid danger. A ready example of this is afforded by the case of a deaf man carelessly approaching a street car track without looking for cars, who was struck the instant he came into the path of the car. The motorman saw him for a long time and sounded his gong. The reasonable man would have realized in time to stop the car that the pedestrian had not heard the bell. Stupidly, the motorman failed to realize this until the impact occurred. The car could have been stopped in 40 feet; the pedestrian could have stopped in his tracks. However superior the motorman's opportunity may be thought, it is not a later one. ${ }^{43}$ None the less most courts allow such a plaintiff to recover and explain his recovery in terms of the last clear chance rule, ${ }^{48}$ though they must strain logic to the breaking point to do so. ${ }^{15}$

If the motorman in the illustration failed to see plaintiff, but only through carelessness, all courts save one or two ${ }^{46}$ would deny plaintiff

look. Cf. Young v. Southern Pac. Co., 189 Cal. 746, 190 Pac. 36 (1920); King v. Connecticut Co., 110 Conn. 615, 149 Atl. 219 (1930); see Perkins v. Terminal R.R. Ass'n of St. Louis, 102 S. W. (2d) 915, 926 (M1o. 1937).

43. All this would be equally true of the case where the motorman fails to aroid the collision because of confusion, stupidity, or the like, after he realizes plaintiff will get on the track.

44. Girdner v. Union Oil Co., 216 Cal. 197, 13 P. (2d) 915 (1932); Cavanaugh y. Boston \& M. R.R., 76 N. H. 68, 79 Atl. 694 (1911); Locke v. Puget Sound I. Ry. \& P. Co., 100 Wash. 432, 171 Pac. 242 (1918); Restatensent, Tosts (1934) §480.

45. That is why the opinions which dissent from this viev seem far more forthright and convincing on the plane of legal reasoning. Mfiddletown Tr. Co. v. Armour \& Co., 122 Conn. 615, 191 Atl. 532 (1937) ; Butler v. Rockland T. \& Co. St. Ry., 99 Me 149, 58 Atl. 775 (1904); see dissenting opinion of Bingham, J., in Cavanaugh v. Boston \& M. R.R., 76 N. H. 68, 74, 79 Atl. 694, 697 (1911). Again (Cf. note 41, supra) it is necessary to distinguish cases based on a failure to show facts which would charge defendant with notice that plaintiff vould continue on into danger, such as Southern Ry. v. Whaley, 170 Tenn. 668, 98 S. W. (2d) 1061 (1936).

46. Missouri and perhaps Virginia. A recent Mrissouri case is Perlins v. Terminal R.R. Ass'n of St. Louis, 102 S. W. (2d) 915 (Mfo. 1937). The rule is well settled in that state under the title of the "humanitarian doctrine." Gaines, The Humarilarian Doctrine in Missoutri (1935) 20 Sr. Lours L. REv. 113; see (1935) 21 VA. L. Rev. 311. In Virginia Ry. \& P. Co. v. Smith \& Hicks, 129 Va. 269, 105 S. E. 532 (1921) the court charged that if defendant failed to use due care to avoid injuring plaintifi after he saw or should have seen him "on or about to cross the track in dangerous proximity to his car, ... " the defendant could be held under the last clear chance doctrine. The instruction was upheld. Cf. Dobson-Peacock v. Curtis, 166 Va. 550, 186 S. E. 13 (1936). 
a recovery and put the denial on the inapplicability of the last clear chance rule. ${ }^{47}$ Yet the two cases are exactly parallel so far as lateness of wrongdoing is concerned. Thus again the decision turns on whether defendant actually sees plaintiff, and disregards the logical implications of professed doctrine wherever he does, though it follows them wherever he does not.

There is another class of cases which falls outside the scope of the formula. Where the plaintiff is negligent, want of "pre-caution" on the part of the defendant should not do as a basis for liability, if only it be not so great as to amount to wantonness. The fact that such default continues to be an efficient proximate cause during every moment until the injury is consummated is no logical reason for regarding it as a fresh wrong committed after plaintiff's own similar want of "pre-caution," for the consequences of that fault, too, are continuing in a manner precisely similar. If a man does the best he can with things as they are, he does no present wrong - even if he could do better with things as they should be, and would be but for some past misdoing. A man's conduct at any given point of time is to be judged in the light of what would then be possible to the standard man in his situation. Of course even this requires impossibilities of the sub-standard person but only to the extent that his individual short-comings are disregarded. It is a wrong not to look for danger when reasonable people would, even though failure to look springs from a habit of inattentiveness which a psychologist might regard as the inevitable outcome of heredity and environment. But if one does look, a failure to see because of poor illumination is no wrong, though there may have been neglect in not affording better illumination at a time when that was possible. The blind man's inability to see is not any more negligent because he lost his eyesight through foolhardiness. Where both negligences are antecedent, and defendant has no chance to avoid the event in the crisis, his may be a graver, but it cannot be a later, wrong.

In the situation we are discussing the great weight of American authority, logically enough, refuses to hold the defendant. ${ }^{48}$ There are

47. The cases cited in note 41 (a), supra, would all support this statement, a fortiori. See, further, cases collected in Note (1934) 92 A. L. R. 47, 128 et seq. (particularly n. 69a); Johnson v. Director General, 81 N. H. 289, 125 Atl. 147 (1924).

48. Bumgardner v. St. Louis Pub. S. Co., 102 S. W. (2d) 594 (Mo. 1937) ; Hagerman v. Rodgers, 101 S. W. (2d) 526 (Mo. App. 1937); Johnson v. Director General, 81 N. H. 289, 125 Atl. 147 (1924); Ramsdell v. John B. Varick Co. 86 N. H. 457, 170 Atl. 12 (1934); Smith v. Norfolk \& S. Ry., 114 N. C. 728,19 S. E. 863,923 (1894); Bohlen, The Rule in British Columbia R.R. Co. v. Loach (1917) 66 Unrv. of Pa. L. Rev. 73; Bohlen, Cases on Torts (3d ed. 1930) 544-547, n. 29. There are not very many American cases expressly dealing with this situation. Countless numbers which do not nevertheless proceed on the tacit assumption that defendant's last chance must be measured on the basis of his speed and the equipment at hand when the crisis arose. See for example Oddwycz y. Connecticut Co., 108 Conn. 71, 142 Atl. 406 (1928); 
one or two dissenting voices, ${ }^{49}$ and in England the defendant is held. ${ }^{\text {to }}$ All cases seek alike to derive their conclusions from the last wrongdoer rule in one form or another. The rationale of the decisions imposing liability may be summed up thus: " . . . a last opportunity which the defendant would have had but for his own negligence is equivalent in law to one which he actually had. He will not be suffered to say that he had not the last opportunity, if he would have had it had he not disabled himself by some prior act of negligence. He who drives a cart when drunk and collides with another vehicle, which he would have had the last opportunity of avoiding if he had been sober, will not be allowed to excuse himself on the plea that in fact he had no such opportunity, because at the critical time he was lying helplessly drunk and asleep at the bottom of his cart." 51 Of course this is just the line of reasoning which courts refuse to apply to plaintiffs in these cases. There may be a justification for such inequality of treatment, but it does not stem from any doctrinal source. ${ }^{\mathrm{t} 2}$

III.

So much for an analysis of the cases in terms of their own reasoning. We see the medieval principle as cardinal. Virtually all the opinions seek

113 Conn. 648, 155 Atly 824 (1931); Virginia El. \& P. Co. v. Ford, 166 Va. 619, 186 S. E. 84 (1936) ; Milby v. Diggs, 189 S. E. 107 (W. Va. 1937).

49. Harper, LAw of Torts (1933) $\$ 139$, n. 79, 81. Some of these dealt with a defendant's inability to see the danger, because of poor headlights. Mfr. Harper says of them: "This result, of course, is sound if the defendant's antecedent negligence consisted in a failure to provide adequate equipment or efficient facilities to discover the plaintiff's perilous situation. Under the rule that a defendant must utilize the last clear chance to avoid the accident after the plaintiff's dangerous situation is discovered or should have been discovered, if the defendant oves a duty to discover the danger, this duty can not be avoided by his failure to provide reasonably adequate equipment to perform it. But if, having discovered the situation, he uses all the facilities at his command to save the plaintiff but the situation has got beyond his control, he should be relieved from the effects of his antecedent negligence, as he is thus quite as helpless as the plaintiff." In this he apparently reflects the stand of the American Law Institute. It is a little hard to see any basis for this distinction. The defendant must see what a reasonable man would have seen. In the same way he must avoid what a reasonable man would have avoided. But why "should have seen" may have the benefit of a further contrary to fact condition, while "should have avoided" may not, I cannot understand. An ingenious but unconvincing justification is put forth but discarded in Lowndes, Contributory Negligence (1934) 22 Gzo. L. J. 674, 706-708.

50. British Columbia El. Ry. v. Loach [1916] 1 A. C. 719.

51. Salmond, LAW of Torts (8th ed. 1934) 482.

52. A few courts employ the last wrongdoer formula to deny recovery to a plaintiff who is violating a statute or ordinance when he is injured. A photographer who is breaking a city ordinance by taking pictures from the middle of the street, for instance, is a wrongdoer every moment he is so engaged; hence a defendant who injures him there can never be the last wrongdoer. Price v. Gabel, 162 Wash. 275, 298 Pac 444 (1931). Contra: Arnold v. Owens, 78 F. (2d) 495 (C. C. A. 4th, 1935). 
to rest on one or another of its forms. Yet if it is properly understood and logically applied, it is not valid as a rule either of exclusion or of inclusion - it does not even coincide with the limits of last clear chance to be found within a single jurisdiction (save possibly Connecticut). This is a curious state of affairs, one which suggests, among other things, that the medieval principle is not a full and complete expression of prevailing notions as to what ought to be done in these cases. If it is not, then why has it had such vitality as a formula; and is it a mere form of words used to cloak actual decisions which conform faithfully to current policy, or does doctrine sometimes thwart common sense? In order to proceed with these inquiries we must try to discover the popular feelings and beliefs about what is expedient and just treatment for accident victims.

On this point I shall begin by stating my hypothesis, for part of its proof will necessarily be the way it accords with what each reader has himself observed in the world about us all. It is this : today people generally feel that only those to blame for an accident ought to be made to pay for it; that if defendant and victim are both at fault, the victim should get something, but not as much as if he had been blameless; that faults should be compared and recovery, somehow, roughly apportioned to them; that in this comparison one whose negligent operation of a dangerous vehicle has endangered others should fare worse than one whose carelessness has exposed only himself to peril.

Conflicting cross-currents of feeling prevent a single-minded adherence to this underlying belief. The most significant of these are: (1) A growing tendency to accept the idea of social insurance, that where losses can be traced to a given form of activity their cost should be distributed among those who benefit by that activity, and should not be borne by those on whom they fall in the first instance, especially where the latter form a class that can ill afford the expense. This cuts athwart theories based on fault and on direct causation alike. Its strongest hold is in the field of industrial accident and employee injuries, but we may well expect to see it engulf the whole field of accident litigation within a generation or so. (2) A feeling of sympathy with the injured victim, the underdog, especially in cases where the defendant is thought able to pay. Till now the effect of these cross-currents, in the field of accidents generally, has probably been confined to making juries resolve most doubts on the question of fault in favor of plaintiffs.

This hypothesis is not susceptible of a high degree of proof, but there is some evidence for it. In the first place, it best explains the instances where last clear chance decisions have deviated from a consistent application of the last wrongdoer formula. Where the peril must be a discovered one, that requirement does not derive from the logic actually used but from a notion that it is not always a greater fault to disregard a later chance - it is not if the chance is merely theoretical, but only if 
it is actual, or "clear." Where a defendant who sees is held liable to a plaintiff who blindly steps into the path of danger, the victim's later opportunity is forgotten because it is felt the defendant's earlier opportunity is so much greater. The same notion explains all the distinctions drawn between defendants who see and those who do not see but should. ${ }^{\text {t3 }}$ Again, where a defendant who cannot see or avoid the danger with the means at hand is held liable for some failure to furnish better means, this result can be tenably rationalized only on a basis of comparative negligence. ${ }^{54}$ In the second place, juries in practice probably decide negligence cases and assess damages in them on a basis of proportional fault. This cannot be demonstrated but it has been noted elsewhere, ${ }^{5}$ and I know it to be the opinion of many jurors and tort trial lawyers. A third piece of evidence pointing to the hypothesis is the growing number of statutes which expressly adopt some scheme of comparative or proportional negligence in accident cases. ${ }^{50}$ Presumably such legislation comes in answer to popular demand. One other thing is suggestive. Something very like comparative fault has often found its way into the best legal circles, thinly disguised by the rule that contributory negligence is no bar to an action based on wilful or wanton misconduct.

Nevertheless, we have seen how the law has steadfastly set its face against openly accepting the legal principle which would best embody the way most people feel and act about cases of negligence. In this impasse the medieval principle has done yeoman service. Taken alone, it strikes no responsive chord in the modern breast - witness our wholesale rejection of it in other fields. Yet here it serves, faute de mieux, because on the whole a want of caution in the crisis seems more blamable than a want of pre-caution. ${ }^{57}$ But the worst wrongdoer is by no means always a last wrongdoer, and there is the difficulty. Our next task, then, is to see whether the old formula, as judicially modified, substantially serves the need for a rule of comparative negligence when this difficulty is encountered. If it does, little can be gained by quarreling with mere language. The law has to some extent accommodated itself to this need, as we have seen; but for the most part it has done so only

53. A comparison of faults on this basis is occasionally involsed to deieat a slointiff who sees the defendant and thereafter negligently gets into danger. Frazier $v$. Stout, 165 Va. 68, 181 S. E. 377 (1935) ; cf. Palmer v. Tschudy, 191 Cal. 696, 242 Pac. 703 (1925) ; Note (1934) 14 B. U. L. REv. 850.

54. 8 Holdsworth, History of English LaW (1922) 462.

55. Ularan, A Judge Takes the Stand (1933) 30-34; Landis, Book Review (1932) 45 HaRv. L. REv. 1428, 1429.

56. Gregory, Legislative Loss Distribution in Neglige:ice Cases (1936) c. 8, collects and describes these statutes.

57. See Kansas City S. Ry. v. Ellzey, 275 U. S. 236, 241 (1927) ("It rests on the assumption that he is the more culpable whose opportunity to avoid the injury was later.") 
in preferring the person negligently unaware of danger to the 'one who is negligent in the light of seen peril. For the rest it is still a matter of carefully measuring times and distances in an effort to find the last wrongdoer. The paths of a pedestrian and a street car cross at an acute angle. The pedestrian is walking with his back partly towards the car engrossed in thought; the motorman is counting his fares. Before either wakes to the situation there is a collision. In Connecticut the pedestrian's right to recover will depend on whether, after he came into its path, the motorman could have stopped or slowed the car or given warning in time to prevent the accident. This calls for a determination of the relative speeds of the parties, the exact position of the car when plaintiff reached the crucial point, and a measurement of the efficiency of the available equipment. ${ }^{58}$ If the car had no brakes or warning device, the defendant will not be held. Nor will he be if the car was going so fast that the equipment was inadequate to prevent the accident after plaintiff has come into the zone of peril. ${ }^{\text {50 }}$ If, on the other hand, the car is going slowly and is well equipped, the plaintiff's chances are better, but still depend on proving a complete ${ }^{60}$ opportunity to avoid harm after he has crossed the magic line made by the forward projection of the car's overhang. It is not enough that the motorman could have taken an effective precaution an instant before that time; it is all-sufficient that he could have done so an instant afterwards.

In most states the pedestrian's case is similar, but harder. The defendant must have a complete opportunity not only after the pedestrian has got himself into the path of the car, but also after he has got to such a point that he cannot get out of its path by ordinary care. ${ }^{61}$ Even then, some jurisdictions will deny recovery if plaintiff was breaking an ordinance against jay-walking.

These results are all logical deductions from one reading or another of the last wrongdoer principle. Tested by a standard of comparative or proportional fault, however, some of them border on absurdity. In the first place, it is highly artificial to make the gravity of defendant's

58. The plaintiff lost his case for want of such evidence in Nehring v. Connecticut Co., 86 Conn. 109, 84 Atl. 301 (1912); Bujnak v. Connecticut Co., 94 Conn. 468, 109 Atl. 244 (1920); Deutsch v. Connecticut Co., 98 Conn. 482, 119 Atl. 891 (1923); Pond v. Connecticut Co., 95 Conn. 437, 111 Atl. 621 (1931) ; cf. Oddwycz v. Connecticut Co., 108 Conn. 71, 142 Atl. 406; 113 Conn. 648, 155 Atl. 824 (1931); Tefft v. N. Y., N. H. \& H. R.R., 116 Conn. 127, 163 Atl. 762 (1933).

59. No Connecticut case directly so holds, but it is assumed that the prevailing American rule would be followed in that state. Of course if the speed or defects in equipment amounted to wantonness, plaintiff could recover.

60. Of course the motorman's opportunity is not complete in a sense that will do anyone any good because he actually is not looking and that fact alone, so far as defendant's conduct goes, would doom the plaintiff.

61. See cases cited in note 41 (a), supra. 
wrong depend on the nicely mechanical timing of a purely theoretical opportunity. No doubt a materially later chance (as in Davies v. Mann) ${ }^{\mathrm{cz}}$ is apt to be thought a better one even where it does no good because defendant is inattentive. But as the matter of timing gets closer, the time element becomes relatively less adequate as a test of the seriousness of the respective wrongs; and questions of timing are very close and very doubtful indeed in the typical last clear chance case of today. ${ }^{\infty 3}$ The illustration, however, reveals a greater flaw than this. Under the formula, it will be seen, it is sometimes true that the greater the defendant's negligence, the less its liability. ${ }^{\text {of }}$ The trolley company may be held for its motorman's failure to look. But if we add to this failure enough other negligence (e.g., as to speed, or equipment) so that looking would not do any good, the trolley company will be let off. Similarly, if the motorman does look and is careful, the company cannot be held where defective equipment renders his care unavailing. It is "in a better position, when [it has] supplied a bad brake but a good motorman, than when the motorman [is] careless but the brake efficient." $c 5$ It would require no little ingenuity to reconcile decisions like these with a scheme of proportional negligence. There is, however, one other note-worthy deduction from the formula to be found in our illustration which might well fit into such a scheme, namely, the denial of recovery to the plaintiff who is violating an ordinance. Nowadays it is a little unusual for people to feel that such conduct is intrinsically worse than what may be called common-law negligence. But such a reaction was once more common, and, after all, these matters belong to the realm of moral value judgment where rational argument is as inappropriate as in the field of taste. If the people of a state feel that way, their law should reflect it, though the issue is only clouded when the decision is couched in terms of concurrent wrongdoing and proximate cause.

Before we can go further in appraising the net result of the formula it would be well to see just how the doctrines of the substantive law of torts impinge upon and affect the actual rights of parties litigant. Legal

62. 10 M. \& W. 545 (Ex. 1842).

63. It is sometimes said that defendant's chance must be materially later. What is usually meant is simply that the defendant may have the bencfit of the time it would take a normal human being to react to an unforseen situation, e.g., a second. Miliby v. Diggs, 189 S. E. 107 (W. Va 1937); see Mforrison v. Boston \& M. R.R. 86 N. H. 176, 180, 164 Atl. 553, 556 (1933). But cf. Swadling v. Cooper [1931] A. C. 1.

64. In this, of course, there is a certain practical safeguard for plaintifis since the human tendency to say what seems to be self-serving has led many a defendant, by exaggerating how careful he was and how good his equipment was, to walk into the trap of last clear chance. Yet it is a trap the wary can avoid. The plaintiff, if indeed his claim in this situation is a worthy one, should not be made to rely on so slender a thing as his adversary's ineptitude.

65. British Columbia El. Ry. v. Loach [1916] 1 A. C. 719, 727. 
rules affect compromises. But negotiations for settlement are conditioned almost entirely by what the parties think would be likely to happen if the course of litigation were pursued. In litigation, rules like those of contributory negligence and last clear chance today seldom cause cases to be won or lost in the pleading stage. Their practical importance makes itself felt at the following points:

1. When plaintiff's right to go to the jury is challenged as upon a motion for a nonsuit, directed verdict, or the like. If on the evidence the plaintiff cannot be held negligent, or if the question of his negligence is doubtful, he is entitled to go to the jury, without having to rely on the last clear chance doctrine at all. ${ }^{66}$ But if upon the evidence a jury would not be permitted to find that the plaintiff was free from contributory negligence, ${ }^{67}$ he can escape immediate defeat only upon showing that the evidence also affords a basis for the application of the last clear chance rule. The penalty for failure to get to the jury is obvious. The reward of a plaintiff's success at this stage is almost as great, since judicial statistics indicate three out of four jury verdicts are in favor of plaintiffs. ${ }^{68}$

2. In the charge to the jury. Here two questions may arise: (a) whether the evidence affords a basis for the application of the last clear chance rule, so that some instruction upon it is proper or required, as the case may be; (b) in what language the instructions upon the rule should be given (assuming the rule to be applicable). The answers to these questions may affect the parties at the hands of the jury or upon appeal.

3. At the hands of the jury. Upon sufficient but conflicting evidence, a jury may find a plaintiff negligent yet be persuaded that defendant had a last opportunity. If they then follow the substantive law as set forth in the charge, they will award plaintiff full damages. In a jtrrywaived case the court, as the trier of facts, may do the same thing.

4. Upon a motion for a new trial. Here the question presented is virtually the same as the one arising upon a motion for a nonsuit or directed verdict.

5. Upon appeal. Here any one or more of the foregoing questions (except the third) may be presented.

66. In this statement and those that follow it is assumed that plaintiff's evidence is sufficient to take him to the jury on the issues of defendant's negligence, proximate cause, and damages.

67. Either because the plaintiff has not sustained the burden of proof upon this issue, or because the defendant has, depending upon where the local law places this burden.

68. Judicial Statistics of the Work of the Supreme Court of New York, 1ST Judictal Department (1930-1935) (the figures given include both tort and other cases); cf. Clark \& Shulman, Law Administration in Connecticut (1937) 74, 213. The proportion of plaintiff's verdicts in Connecticut seems somewhat lower. 
If it is true that people generally think and feel in terms of comparative or proportional fault, and if juries on the whole decide cases in terms of such popular notions and prejudices, ${ }^{69}$ then it follows that the technical requirements and limits of the last clear chance will not greatly hamper their deliberations or prevent them from reaching results which in the main satisfy public opinion. As a matter of fact, I believe that is just the case. Moreover, it does not greatly matter just what language on this issue finds its way into the charge, so far as the verdict is concerned. Such instructions are likely to be complicated and very hard to understand anyway. A lay tribunal will cut the Gordian knot of legalism. So far as ability to perform their theoretical function is concerned, the weakness of the jury is the strength of the law - especially in situations like this where the rules to be found in the books are so imperfect an expression of deep-seated popular feeling. ${ }^{70}$ But what the jury does is not the whole story. First a plaintiff must get to the jury; then, if he obtains a verdict, he must be able to hold it in the trial and appellate courts. It is at these points that doctrine comes into its own. Before a plaintiff whose own negligence is an issue in the case can have his fault and his adversary's judged according to prevailing lay notions of justice, he must do homage to the medieval principle. This principle, to be sure, coincides in part with prevailing notions and is often distorted to coincide with them a little more fully. Yet there are serious discrepancies. And the search for a last wrongdoer has generated detailed rules of thumb which have no place in a scheme of comparative negligence. We observed these things in the field of substantive law when

69. "I confess that in my experience I have not found juries specially inspired for the discovery of truth. I have not noticed that they could see further into things or form a saner judgment than a sensible and well trained judge. I have not found them freer from prejudice than an ordinary judge would be. Indeed one reason why I believe in our practice of leaving questions of negligence to them is what is precisely one of their gravest defects from the point of view of their theoretical function: that they will introduce into their verdict a certain amount $-a$ very large amount so far as $I$ have observed-of popular prejudice, and thus keep the administration of the law in accord with the wishes and feelings of the community. Possibly such a justification is a little like that which an eminent English barrister gave me many years ago for the distinction between barristers and solicitors. It was in substance that if the law was to be practiced somebody had to be damned, and that he preferred that it should be somebody else." Holares, Coliected Legal Papers (1921) 237.

70. If this is true, "reforms" such as compulsory special verdiets or answers to interrogatories (which are calculated to make the jury perform its theoretical function more perfectly) are steps in the wrong direction. Sce Tuayer, Preummaizi Treatise ON THE LAW OF Evidence (1898) 217-219.

Further, this consideration must not be lost sight of in those worthy attempts to cut down calendar delay and the expense of litigation by exerting pressure on litigants to waive juries. There is little doubt that judges, in trying facts, will be more inhibited by vestigial doctrine than juries. 
we discussed the illustration of the pedestrian and the inattentive motorman. Translated into practice, the net result of all this is twofold: (1) It makes the matter of getting to the jury (or of holding a favorable verdict) turn on factors which are capricious, complicated, and often irrelevant to those considerations which should occupy the courts. (2) It makes instructions to the jury a constant source of error and reversal, even of verdicts sustainable on the evidence. ${ }^{71}$ The question whether the issue should have been presented in the charge at all is similar to that of getting to the jury, and involves the same factors. ${ }^{72}$ The language in which such an instruction must be cast (where one is called for) is necessarily so intricate and incomprehensible that there is a good chance the judge will make some technical misstatement and be reversed on appeal.

Of course these difficulties would all be swept away by a statutory adoption of the principle of proportional fault. Others might be encountered. ${ }^{73}$ Certainly if such a system is coupled with its rather logical corrolary of contribution between co-tortfeasors, serious complications might arise. ${ }^{74}$ So greatly to emphasize fault might in more ways than one tend to thwart an already perceptible and perhaps welcome trend towards the imposition of liability without fault. ${ }^{75}$ Quite possibly the legislatures will respond to this trend before comparative or proportional negligence is extensively enacted into statutes. In the meantime the courts will not, in all probability, adopt either scheme expressly. If there is any development here, it is likely to be along the lines of the enlargement of the jury's sphere in negligence cases ${ }^{76}$ and further liberalizing of the

71. Examples are Mosso v. Stanton Co., 75 Wash. 220, 134 Pac. 941 (1913); Kirkham v. Jenkins Music Co., 104 S. W. (2d) 234 (Mo. 1937); Borgstede v. Waldbauer, 337 Mo. 1205, $88 \mathrm{~S}$. W. (2d) 373 (1935). In fairness it must be said that many jurisdictions have already crystallized the language of last clear chance instructions so that chances of error on this score are greatly reduced.

72. Malfetano v. United El. Rys., 191 Atl. 491 (R. I. 1937).

73. I suggest that the supposed difficulty juries would have in apportioning fault would present no real problem in practice, except in the eye of those who might hope for a mathematical nicety of adjustment.

74. Attempts to apportion damages among all of those involved in an accident would involve an exceedingly complicated machinery. See GREGORY, LEGISLATIVE LOSS Distribution in NeGLigenCe CAses (1936) for such an attempt, carefully worked out.

75. See James, Book Review (1936) 4 UnIv. of Crr. L. REv. 158.

76. There has been noted a growing reluctance to hold plaintiffs guilty of contributory negligence as matter of law. Nixon, Changing Rules of Liability in Automobile Accident Litigation (1936) 3 Law \& Contearr. Prob. 476. This, as we have seen, diminishes the necessity of reliance on last clear chance with its foibles. There are other ways in which the jury's scope may be enlarged. A court may, for example, take a broad view of the sufficiency of evidence to prove one of the facts necessary for the application of last clear chance. The Iowa court seems to do this with respect to proving that the defendant saw plaintiff in time to avoid him. See review of authori- 
rules of last clear chance through an increasing distortion or abandonment of the legalistic and logical bases of the doctrine. This tendency has been marked to date ${ }^{\pi 7}$ and will no doubt continue. Its future course will probably lead tortuously nearer to the path of comparative negligence, but litigants for some time to come will occasionally be sacrificed on the altar of accurate reasoning from outworn premises. The real solution for the present lies in the jury and in the approval of simpler and vaguer formulas in instructions to the jury so that error on this score will become less frequent.

ties in Groves v. Webster City, Iowa, 222 Iowa 849, 270 N. W. 329 (1936); cf. Tullock v. Connecticut Co., 94 Conn. 201, 209, 108 Atl. 556, 559 (1919). There are vide limits, too, within which a court may accept or reject the tendency of evidence to show that defendant should have realized plaintiff's impending peril when he still could act. Compare Pond v. Connecticut Co., 95 Conn. 437, 111 Atl. 621 (1931) with Panarese v. Ünion R.R., 261 N. Y. 233, 185 N. E. 84 (1933); Dobson-Peacocls v. Curtis, 165 Va. 550, 186 S. E. 13 (1936) with Southern Ry. v. Whaley, 170 Tenn. 668, 98 S. W. (2d) 1061 (1936).

77. Compare Young v. Southern Pac. Co., 189 Cal. 746, 190 Pac. 36 (1920) with Darling v. Pac. El. Ry., 197 Cal. 702, 242 Pac. 703 (1925) and Girdner v. Union Oil Co., 216 Cal. 197, 13 P. (2d) 915 (1932); see also Rasmussen v. Fresno Tr. Co, 15 Cal. App. (2d) 556, 59 Pac 617 (1936). Compare Smith $\nabla$. Norfolls \& S. Ry., 114 N. C. 728, 19 S. E. 863, 923 (1894) with Micklanus v. Seaboard Air Line Ry., 174 N. C. 735, 94 S. E. 455 (1917) ; Southern Ry. v. Bailey, 110 V2. 833, 67 S. E. 365 (1910) with Gunter's Adm'r v. Southern Ry., 126 Va. 565, 101 S. E 885 (1920). Keller v. Norfolk \& W. R.R., 109 W. Va. 522, 528, 156 S. E 50, 52, 53 (1930) with Smith v. Gould, 110 W. Va. 579, 159 S. E. 53 (1931). In some cases the dissenting judges point out that the decision goes beyond anything warranted by loeal precedent. Perkins v. Terminal R.R. Ass'n of St. Louis, 102 S. W. (2d) 915, 924,930 (A5o. 1937), Cavanaugh v. Boston \& MI. R.R., 76 N. H. 68, 74, 79 Ati. 694, 697 (1911). 